\title{
Local structure of a peptide contact site on $A_{\alpha}^{k}$
}

\author{
Bing-Yuan Wei, Nadine Gervois, Georges Mer, Luclano Adorini ${ }^{1}$, \\ Christophe Benoist, and Diane Mathis
}

Laboratorre de Génétique Molécularre des Eucaryotes du CNRS et Unité 184 de l'Inserm, Faculté de Médecine, Institut de Chımıe Biologique, 11, rue Humann 67085 Strasbourg Cédex, France

1Preclinical Research, Sandoz, Pharma Ltd, CH-4002 Basel, Switzerland

Key words. MHC class II, mutagenesıs, structure/function, antıgen presentation

\begin{abstract}
We have sought to determine how much amino acld diversity is tolerable at position 69 of the $A_{\alpha}^{k}$ chain, a position previously implicated as a peptlde contact site. Slot-machine mutagenesis was used to create a set of 11 mutant $A_{\alpha}^{k}$ CDNAs, each specifying a different amino acid at position 69. These cDNAs were Individually expressed In $L$ cells together with a wild-type $A_{\beta}^{k}$ CDNA to produce a panel of mutant antigen-presenting cell lines. The ability of each member of this panel to present a hen egg lysozyme and a bovine ribonuclease peptide to varlous $T$ hybridomas was assessed. We found that a surprising degree of amino acid diversity is tolerable at $A_{\alpha}^{k}$ position 69: even charged (Glu, Arg) or bulky (Trp, Tyr) residues can be accommodated without abrogating cell-surface expression of $A^{k}$, peptide binding to $i t$, or $T$ cell recognition of it. We discuss the Implications of these findings for models of $\mathrm{T}$ cell recognition of the class II molecule/antigen duplex.
\end{abstract}

T cell receptors only recognize $\mathrm{Ag}$ in the context of an $\mathrm{MHC}$ class I or class II molecule. The exact nature of the TCR-MHC molecule - Ag ternary complex remains somewhat enigmatıc, although some major advances in our understanding have taken place over the past several years. The image of a class I molecule derived from the crystal structures of HLA-A2 $(1,2)$ and HLAAw68 (3) has provided a framework for interpreting functional data (4). It has also prompted Brown et al. to model the antigen binding site on a class II molecule (5). Their model predicts that the class $\| \alpha_{1}$ and $\beta_{1}$ domains associate in a manner very sumilar to the class I $\alpha_{1}$ and $\alpha_{2}$ domains: an antıgen-binding groove is formed by an alpha-helix from the $\alpha$ chain, an alpha-helix from the $\beta$ chain and underlying beta-sheets from both. Most polymorphic residues are located within this Ag-binding groove, and their side chains generally point either into or up from the groove, as might be expected for Ag and TCR contacts, respectively.

Alanine-scan mutagenesis of the alpha-helix on the $A_{\alpha}^{k}$ chain has recently provided substantial support for the model of Brown et al. (6). For example, the interpretation of data from diverse functional assays converged to implicate several 'in-pointing' residues as direct peptide contact sites. Let us consider the case of residue 69. First of all, an Ala substitution at this position had a drastic effect on the presentation of hen egg lysozyme (HEL) and bovine pancreatic ribonuclease (RNase) peptıdes to all of the Thybridomas analyzed (at that tume), save one that appeared to recognize its cognate peptide with much lower affinity than the others. Second, Ala replacement of the usual Thr at position 69 provoked one of the hybridomas, normally specific for an RNase peptide, to recognize the $A^{k}$ complex alloreactively. This observation was considered in the context of the recent evidence that many alloreactive $T$ cells actually respond to a peptide in the groove of the $\mathrm{MHC}$ molecule (for discussion and references, see 7). And third, the peptide RNase 43-56 was not recognized in the context of an $A^{k}$ complex carrying a mutation at $\alpha$ chain position 69 , but an analogue of this peptide bearing a single amıno acid replacement was seen quite effectively. Together, these three observations argued forcefully that the residue at this position can directly interact with peptide antigens (but see more extensive discussion in 6).

Having identified in this manner several resıdues likely to be peptide contact sites (6), we wondered about the structure of such critical locales and about the chemical interactions that might be in play. Would $\mathrm{Ag}$ binding to the MHC molecule and TCR recognition of the resulting $\mathrm{MHC}$ molecule/Ag duplex be tolerant of local stuctural perturbations? Or would either show the exquisite specificity we previously demonstrated for antibody recognition of the $A_{\alpha}$ chain (8)? To address this issue, we have created a panel of mutant antigen-presenting cell (APC) lines, each expressing an $A^{k}$ complex with a different amino acid at 


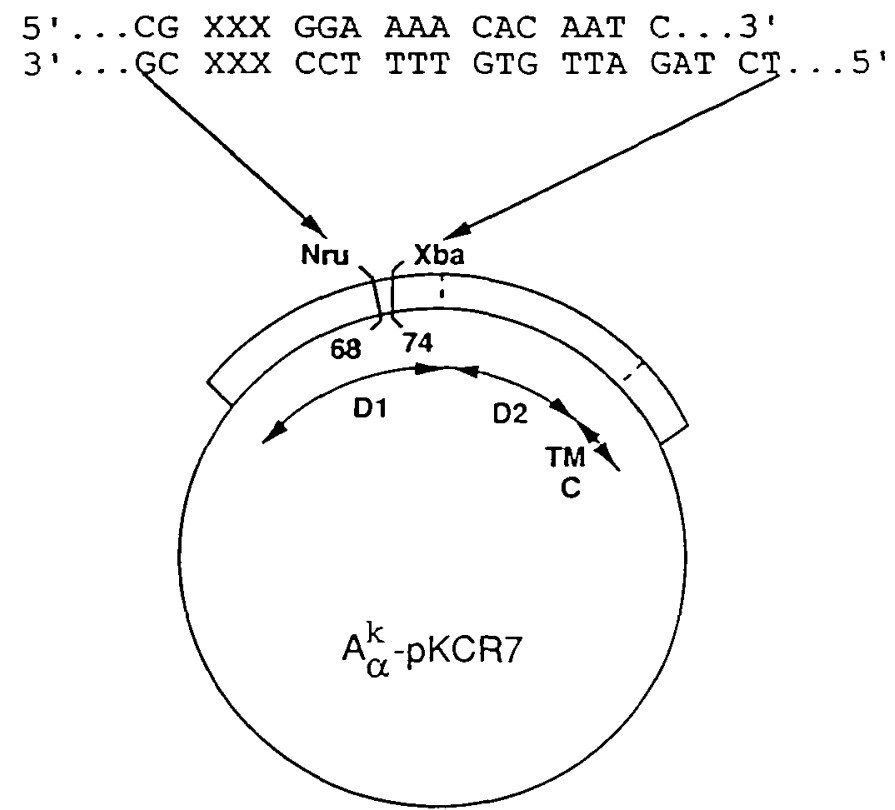

Fig. 1. Mutagenesis strategy. The plasmid $A_{\alpha}^{k}$-pKCR7 contans an $A_{\alpha}^{k}$ CDNA in the expression vector pKCR7 $(6,8)$. The domans of $A_{\alpha}$ are indicated as D1, the membranedistal domain; D2, the membraneproximal domain; $T M$, the transmembrane region; $C$, the cytoptasmic tal The cloning vector was prepared by cutting at the (artificial) Nrul and $X$ bal stes, leaving a gap at the nucleotides coding for amino acids $68-74$. This gap was filled va ligation of the double-stranded oligo $m i x$ whose sequence is given and which is described in more detail in the text $X X X$ marks the positions of the three nucleotides coding for amıno acid 69 , and represent random incorporation of the four bases at each position

position 69 of the $\alpha$ chain. The ability of the panel members to present antigenic peptides to diverse HEL-specific and RNasespecific $T$ cell hybridomas was then evaluated.

Slot-machine mutagenesis ( 8 ) was used to create a series of mutant $A_{\alpha}^{k}$ cDNAs. First, two mixtures of complementary oligonucleotides (oligos) were synthesized as indicated in Fig. 1. During the synthesis of each, we permitted random incorporation of the four nucleotides at the target site-the triplet encoding $A_{\alpha}^{k}$ amino acid 69 . Next, the two complementary oligo mixes were annealed and ligated to $A_{\alpha}^{k}$-pKCR7 to replace the corresponding stretch of an $A_{\alpha}^{k}$ cDNA in the pKCR7 expression vector (Fig. 1). The ligation products were transfected into $E$. coli, 80 colonies were selected randomly, small amounts of plasmid DNAs were prepared from each, and the DNAs were sequenced in the vicinity of the target site. A wild-type $A_{\alpha}^{k}$ cDNA and several position 69 mutants were obtained; the entire first domain of each was then sequenced. These constructs were individually transfected into $L$ cells together with an expressible wild-type $A_{\beta}^{k}$ cDNA and a selection marker $(8-10)$. The transfectants displaying surface $A^{k}$ molecules were electronically sorted using the pan-la monoclonal antibody (mAb) 40B, and expanded.

All of the mtuant $A_{\alpha}^{k}$ chains associated with wild-type $A_{\beta}^{k}$ and, without exception, the resulting complexes were expressed at the cell surface. Transfectant lines expressing roughly similar surface levels of $A^{k}$ molecules could easily be obtained, as shown in Fig. 2 for some cases. These qualitative results suggested that none of the $A_{\alpha}$ position 69 substitutions grossly

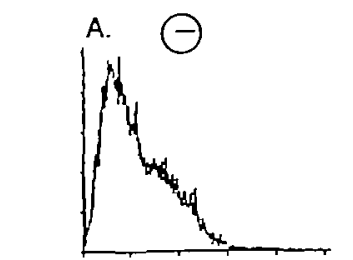

B. WT

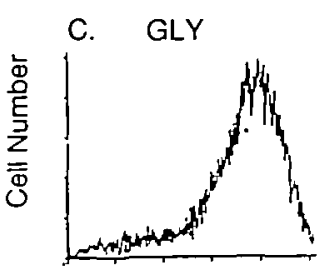

D. GLU

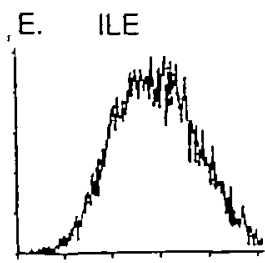

F. TRP

Fluorescence Intensity

Fig. 2. $A^{k}$ expression on $L$ cell transfectants Aliquots of a wild-type and representative mutant transfectant(s) were stained with the ants- $A_{B}^{k}$ reagent 102.16 , and were analyzed by cytofluorımetry as described $(6,8-10)$; - , non-transfected control; $W T$, mid-type $A_{\alpha}^{k}$, Gly, Glu, lle, Trp, amino acids replacing the Thr at position 69 on the $A_{\alpha}^{k}$ chain Honzontal axis: fluorescence intensity on a 2-decade log scale.

affect the assembly, transport, cell-surface expression and overall conformation of the $A^{k}$ complexes-even with such radical amıno acid replacements as Glu, Arg, or Trp.

The ability of the mutant lines to present the peptıdes HEL 46-61 and RNase 41-61 to a panel of T cell hybridomas, whose properties are listed in Table 1, was then assessed. Typical dose-response curves are illustrated in Fig. 3, and the presentation efficiencies derived from such curves are listed in Table 2.

Four points emerge as salient:

(i) All of the mutant $A^{k}$ complexes were recognized well by at least one of the hybridomas, supporting our contention that the structure of the complex is not grossly perturbed by any of the $A_{\alpha}$ position 69 substitutions. This result also implies that all of the mutant $A^{k}$ complexes remain capable of binding the peptides tested.

(ii) The amino acid replacements which seemed to have the most profound effect on antigen presentation were those which involve charged or bulky residues, i.e. those at the right-hand side of Table II.

(iii) There was a wide range in the sensitivity of the different Thybridomas to replacements at position 69 of the alpha chain: $3 A 9$ and kLy 11.10 did not recognize any of the mutant $A^{k}$ complexes, while $2 \mathrm{B5} .1$ responded to all of them, often better than to the wild-type complex.

(iv) As has been discussed elsewhere (7), an Ala replacement at $A_{a}^{k}$ position 69 provokes an alloresponse from the RNasespecific hybridoma R37. Interestıngly, none of the other replacements behaved in a similar fashion. 
Table 1. Properties of the T hybridomas

\begin{tabular}{|c|c|c|c|c|c|}
\hline \multirow[t]{2}{*}{ T hybridoma } & \multirow[t]{2}{*}{ Source } & \multirow[t]{2}{*}{ Immunogen } & \multicolumn{2}{|l|}{ TCR } & \multirow[t]{2}{*}{ Reference } \\
\hline & & & $V_{\beta}$ & $v_{\alpha}$ & \\
\hline \multicolumn{6}{|l|}{ HEL-specific } \\
\hline 3A9 & CBAJ & HEL & 8.2 & 3 & 13 \\
\hline kLy 1110 & $B 10 A(4 R)$ & HEL & 11 & 1 & 14; S. Candeias, unpublished \\
\hline KLy 4.10 & $\mathrm{~B} 10 \mathrm{~A}(4 \mathrm{R})$ & HEL & 11 & & E. Rosloneic, unpublished \\
\hline $1 \mathrm{G} 5$ & $\mathrm{C} 3 \mathrm{H}$ & HEL & 6 & 1 & N. Gervois, unpublished \\
\hline 3D3.1 & $\mathrm{C} 3 \mathrm{H}$ & $\mathrm{HEL}$ & 8.3 & 1 & N. Gervois, unpublished \\
\hline $1 \mathrm{~A} 3.2$ & $\mathrm{C} 3 \mathrm{H}$ & HEL & 82 & 44 & N. Gervois, unpublished \\
\hline 2B5 1 & $\mathrm{C} 3 \mathrm{H}$ & HEL & 83 & 1 & N. Gervois, unpublished \\
\hline \multicolumn{6}{|l|}{ RNase-specific } \\
\hline TS12 & CBAJJ & RNase & 2 & 1 & S Canderas, unpublished \\
\hline R37 & $B 10 . A(4 A)$ & RNase $41-61$ & 6 & 4 & S. Candeias, unpublished \\
\hline
\end{tabular}
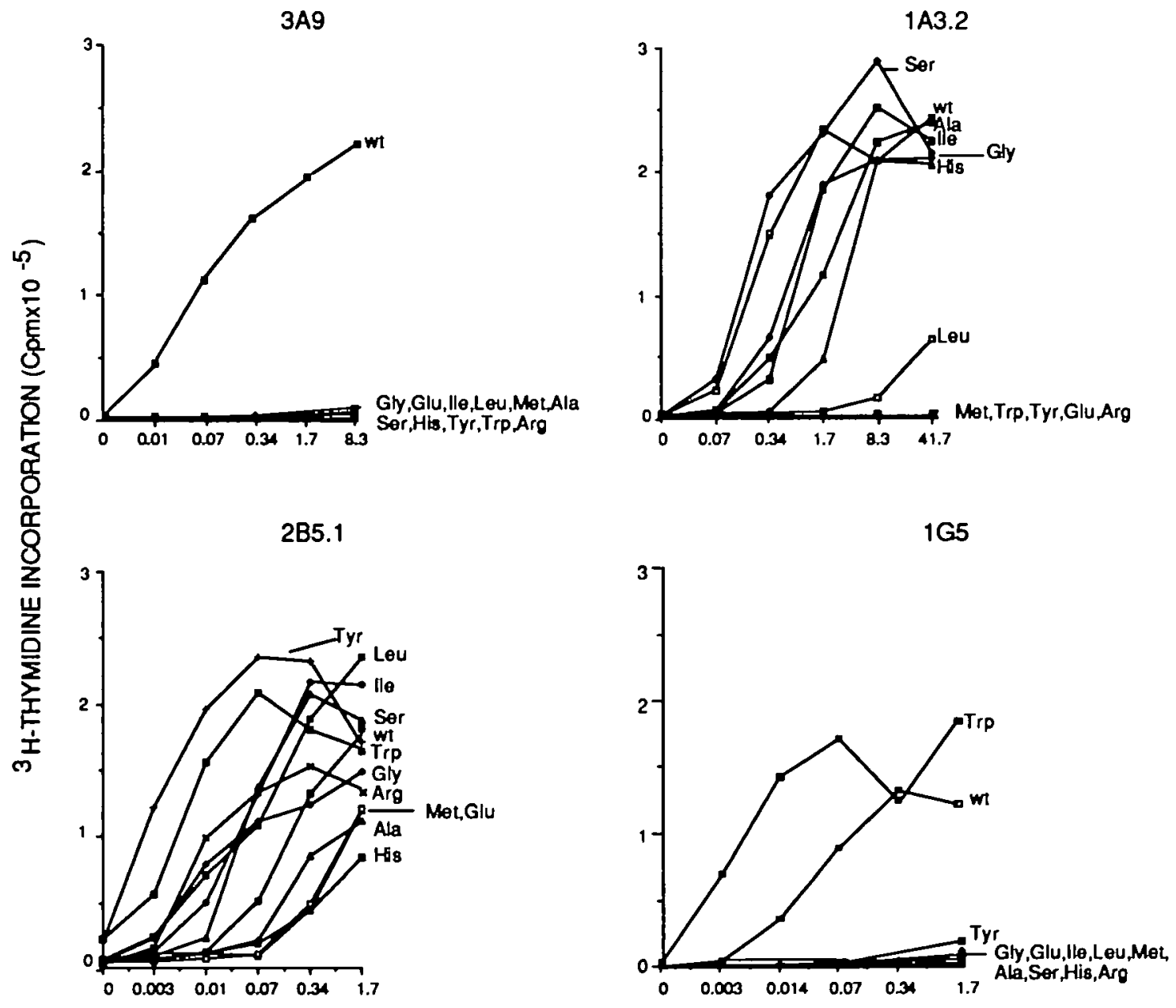

ANTIGEN CONCENTRATION $(\mu \mathrm{g} / \mathrm{ml})$

Fig. 3. Dose - response curves. $L$ cells expressing wildtype or mutant $A^{k}$ molecules were used as antigen presenting cells. The assays were performed in 96-well microtiter plates by incubating $5 \times 10^{4}$ APCs with $5 \times 10^{4}$ Thybridomas and 5 -fold dilutions of antugenic peptide in a total volume of $300 \mu$. The highest concentration of HEL and RNase peptides was usually $5 \mu \mathrm{g} / \mathrm{ml}$. In the negative controfs, no antigen was added. After incubation for $24 \mathrm{~h}, 50 \mu$ of supernatant was collected and tested for IL-2 content using the CTLL assay, for which $10^{4} \mathrm{CTLL}$ cells were used. From the dose - response curves obtained for each mutant $L$ cell line, the antigen presentation efficiency $(W / M)$ was calculated. $W$ represents the antigen concentration required by the wild-type KK cell line to elicit a hall-maximum IL-2 response from the T hybridomas, while $M$ indicates the antigen concentration required by the mutant to eficit the same levet of IL-2 production. 
836 Slot-machine mutagenesis of a peptide contact site

Table 2. Presentation efficiencies of the mutant APC lines to the various $T$ hybridomas

\begin{tabular}{|c|c|c|c|c|c|c|c|c|c|c|c|}
\hline \multirow[t]{2}{*}{$\mathrm{T}$ hybridoma } & \multicolumn{11}{|c|}{ Substutution at $A_{\alpha}^{k}$ position 69} \\
\hline & $\begin{array}{l}\text { Gly } \\
\text { K69G }\end{array}$ & $\begin{array}{l}\text { Ala } \\
\text { K69A }\end{array}$ & $\begin{array}{l}\text { Ser } \\
\text { K69S }\end{array}$ & $\begin{array}{l}\mathrm{lle} \\
\mathrm{K} 69 \mathrm{I}\end{array}$ & $\begin{array}{l}\text { Leu } \\
\text { K69L }\end{array}$ & $\begin{array}{l}\text { Met } \\
\text { K69M }\end{array}$ & $\begin{array}{l}\text { Trp } \\
\text { K69W }\end{array}$ & $\begin{array}{l}\text { Tyr } \\
\text { K69Y }\end{array}$ & $\begin{array}{l}\mathrm{His} \\
\mathrm{K} 69 \mathrm{H}\end{array}$ & $\begin{array}{l}\text { Glu } \\
\text { K69E }\end{array}$ & $\begin{array}{l}\text { Arg } \\
\mathrm{K} 69 \mathrm{R}\end{array}$ \\
\hline 3A9 & - & - & - & - & - & - & - & - & - & - & - \\
\hline kLy 1110 & - & - & - & - & - & - & - & - & - & - & - \\
\hline kLy 4.10 & - & 001 & 0.02 & - & - & - & - & - & - & - & - \\
\hline $1 \mathrm{G5}$ & - & - & - & - & - & - & 2 & 0.002 & - & - & - \\
\hline 2B5.1 & 1.5 & 04 & 1.5 & 2.2 & 4 & 0.5 & 2.0 & 20 & 3.0 & 0.07 & 2.3 \\
\hline \multicolumn{12}{|l|}{ RNase-specific } \\
\hline TS12 & - & - & - & - & 0.01 & - & - & - & - & - & - \\
\hline $\mathrm{R} 37$ & 0.7 & allo & 0.65 & - & - & - & - & - & - & - & - \\
\hline
\end{tabular}

Experiments were performed at several peptide concentrations (wth 5 -fold dilutions) as well as in the absence of peptide. Presentation efficiencies were calculated as described in Methods. The values are averages of three to four independent experiments, variations between experıments were within a few-fold, at most, of the average shown. Bars indkate undetectable presentation (efficiencies $<0.001$ ) In some experıments, a marginal response was observed and this is indicated by an asterisk. Stimulation of a hybridoma in the absence of peptıde is recorded as allo.

What implications do these results have for models of the TCR - MHC molecule - Ag ternary complex?

Previous experıments implicated position 69 on the $A_{\alpha}^{k}$ chain as a peptide contact site (6). Here, we have sought to determine just how much structural variation can be tolerated at this position. Our results indicate that diverse amıno acids, of radically different chemistry, can be accommodated at position 69 without grossly disturbing the assembly, transport, cell-surface expression or overall conformation of the mutant $A^{k}$ complexes. Most astonishingly, these diverse amino acid substitutions are also compatıble with binding of both peptides tested, since all of the mutant APC lines presented to at least one of the hybridomas. These substitutions include amino acids with the very bulky Trp and Tyr side-chains, which might be expected to virtually fill up the groove locally. On the other hand, $T$ cell recognition is clearly influenced by the various substitutions, but there is tremendous variation in the effect of antigen recognition by the different hybrıdomas, ranging from exquisite sensitivity to near-total insensitivity.

These observations can be compared with findings from a similar set of experiments on position 75 of the $A_{\alpha}^{k}$ chain, a position that is 'up-pointıng' according to the model of Brown et al., and thus presumably involved in TCR contacts (8). In this former study, we employed $T$ hybridomas of different antigen specificity (allo), but the results were very comparable to those from the present study: assembly, transport, etc. of the $A^{k}$ complex were largely unaffected by diverse amıno-acid substitutions; T cell reactivity was affected but there was great variety in the individual patterns of recognition. Since position 75 had been predicted to be a $T$ cell receptor contact residue, these findings were precisely what one might have expected. The surprise is that mutations at position 69, a putative peptide contact residue, lead to such similar findings. One would have expected that all T cells specific for a given peptide would either recognize, or not, a particular substitution, according to whether it permitted, or not, peptide binding.

Resolution of this dilemma probably lies in a more sophısticated view of the TCR - MHC molecule-Ag triplex. For example, there may not be such a clear distinction between TCR-MHC molecule, MHC molecule-Ag and $\mathrm{Ag}-\mathrm{TCR}$ contacts. It is possible that the $\mathrm{MHC}$ molecule moulds the $\mathrm{Ag}$ into a particular conformation $(6,11)$ and different features of this molded structure are recognized by different $T$ cells. Followng this line of reasoning: contact at position 69 would induce a particular 'nook' or 'cranny' in the tertiary structure of the peptide; some T cells would find this feature totally irrelevant, others would require its exact form, and still others might require its existence but permit some flexibility in its precise form.

Alternatively, it might be that a single peptide is variably disposed within the groove of the class II molecule when partıcıpatıng in different TCR-MHC molecule-Ag triplexes. According to this view, the peptide would fit loosely in the groove-resonating between various positions and/or conformations while making multiple (each non-essential) contacts-until the TCR 'docks on' and locks in a particular disposition. For a given peptide, the allowable positions or conformations could be quite variable, as extreme as register shifts from one end of the groove to the other. Mutations at peptide contact sites on the MHC molecule could prevent, to varying degrees, the different peptide dispositions: position 69 would be critical for recognition by some $T$ cells because it takes part in anchoring the peptide at their recognition site; other $T$ cells would be insensitive to position 69 substitutions because the disposition they recognize does not involve this position. An extreme case might be represented by the T hybridoma 2B5.1-it responds to all of the mutant APC lines and its activation is actually enhanced by the Trp and Tyr substitutions. One could hypothesize that the 2B5.1 recognizes the HEL peptide in a position shifted away from residue 69 . By essentially blockıng off the groove, the bulky Trp or Tyr side-chains could actually favor this alternative disposition.

The need for a more sophisticated view of $T$ cell recognition was also apparent from the results of the alanine-scan mutagenesis experiments of Peccoud et al. (6). Certain in- 
pointing' residues, including the threonine at position 69 , appeared to be direct peptide contacts according to diverse functional criteria; yet competition experiments indicated that alanine replacements at these positıons, while drastically aftecting T cell recognition, still permitted peptide binding. Similarly, Freed and co-workers showed that mutations at position 69 (Thr $\rightarrow$ Ile) and 79 (Lys - Glu) in the JE50 B lymphoma line severely affected recognition by most hybridomas but still allowed peptide binding (12). The possibility remained that these surprising and somewhat disturbing findings reflected the partıcular amino acid replacements-alanine, in particulas, being small, uncharged and generally rather innocuous. The present study renders this interpretation inviable.

The two slot-machine mutagenesis experıments $(8$ and this study) reveal an additional important aspect of the structure of class II molecules. Chemically extreme alteratıons at positıons 69 and 75 do not prevent cell-surface expression of an $A^{k}$ complex that is capable of binding peptide and of being recognized by at least some $T$ cells. This reveals the great flexibility of the $A_{\alpha}$ alpha helıx and underlines its structural independence from other features of the molecule. Thus, evolution seems to have provided a secondary structure optumally suited to accommodating the polymorphism this chain's function demands.

\section{Acknowledgements}

We are grateful to Dr $P$ Allen for the gitt of peptides, to Drs J. Freed $E$ Rosloniec, and $P$. Allen for cell lines, to $C$ Waltzinger for help with the cytofluorimetric analysis, to $\mathrm{S}$. Candelas for communicating unpublished sequencing results, and to $P$. Gerber and $C$ Ebel for technical assistance This work was supported by institutional funds from the INSERM and the CNRS and by a grant to D M and C B from the Association pour la Recherche Contre le Cancer. B. Y W received a fellowship from the INSERM and N.G. from the Groupement des Entreprises Françases dans la Lutte Contre le Cancer.

\section{Abbreviations}

$\begin{array}{ll}\text { APC } & \text { antıgen presentıng cell } \\ \text { HEL } & \text { hen egg lysozyme } \\ \text { oligo } & \text { oligonucleotide } \\ \text { RNase } & \text { ribonuclease }\end{array}$

\section{References}

1 Bjorkman, P J, Saper, M. A., Samraoui, B., Bennett, W. S., Strominger, J. L., and Widey, D C. 1987. Structure of the human class I histocompatibility antigen, HLA-A2. Nature 329:506.

2 Bjorkman, P J. Saper, M. A., Samraoui, B., Bennett, W. S., Strominger, J. L., and Wiley, D. C. 1987. The foreign antigen binding site and $T$ cell recognition regions of class I histocompatibility antigens Nature 329:512

3 Garrett, T P. J., Saper, M. A., Bjorkman, P. J., Strominger, J L., and Wiley, D C 1989. Specificity pockets for the side chains of peptide antigens in HLA-Aw69. Nature 342:692.

4 Bjorkman, P. J and Parham, P. 1990. Structure, function and diversity of class I major histocompatibility molecules. Annu. Rev Brochem. 59253.

5 Brown, J. H., Jardetzky, T , Saper, M. A., Samraoul, B., Bjorkman, P J., and Wiley, D. C. 1988. A hypothetıcal modet of the foreign antigen binding site of class II histocompatublity molecules. Nature $332 \cdot 845$

6 Peccoud, J., Dellabona, P., Allen, P., Benorst, C., and Mathis, D. 1990. Delineation of antigen contact residues on an $\mathrm{MHC}$ class II molecule. EMBO J. $9 \cdot 4215$.

7 Dellabona, P., Wei, B -Y., Gervois, N., Benoist, C., and Mathis, D. 1991. A single amino acid substitution in the $A^{k}$ molecule fortutuousty provokes an alloresponse Eur. J. Immunol. 21209

8 Landais, D., Marchetto, S, Waltzinger, C., Pierres, M , Benorst, C., and Mathis, D 1988. Slot-machine mutagenesis of a polymorphic residue on the $A_{\alpha}^{k}$ chain. $J$ Immunot. 141.667.

9 Landars, D., Beck, B. N., Buerstedde, J. M., de Gaw, S, Klenn, D, Koch, N., Murphy, D., Pierres, M , Tada, T., Yamamoto, T., Benoist, C., and Mathis, D.1986 The assignment of chain specificities for anti-la monoclonal antibodies using $\mathrm{L}$ cell transfectants $J$. Immunol $137 \cdot 3002$

10 Landais, D., Watzzinger, C., Beck, B N., Staub, A., McKean, D. J., Benoist, C., and Mathıs, D 1986. Functional sites on la molecules. a molecular dissection of Aa immunogenicity. Cell 47:173

11 Brett, S. J., McKean, D, York-Jolley, J., and Berzofsky, J. A. 1989. Antıgen presentatıon to spocific $T$ cells by la molecules selectively altered by site-directed mutagenesis Int. Immunot 1.130 .

12 Rostoniec, E F., Vitez, L J , Beck, B. N., Buerstedde, J.-M., Mckean, D. J., Benoist, C., Mathis, D., and Freed, J H 1989 I-Ak polymorphisms define a functionally domınant region for the presentation of hen egg lysozyme peptides. J. Immunot. 143.50

13 Johnson, N. A , Clarland, F, Allen, P. M., and Glımcher, L. H. 1989 $T$ cell receptor gene segment usage in a panet of hen-egg white Iysozyme specific, I-A ${ }^{k}$-restricted Thelper hybridomas. J. Immunot 142.3298.

14 Rostoniec, E. F, Gay, D., and Freed, J. H. 1989. Epitopic analysis by anti-l- $A^{k}$ monoclonal antibodies of $1 . A^{k}$-restricted presentation of lysozyme peptıdes. J. Immunol 142.4176 